The Labore Journal of Economics

$10: 2$ (Winter 2005) pp. 87-99

\title{
The Exchange Rates and Monetary Dynamics in Pakistan: An Autoregressive Distributed Lag (ARDL) Approach
}

\author{
Muhammad Arshad Khan* \& Muhammad Zabir Sajjid**
}

\begin{abstract}
In this paper we investigate both the long and short-run relationship between real money balances, real income, inflation rate, foreign interest rate and real effective exchange rate with reference to Pakistan over the period 1982Q2-2002Q4 using ARDL approach which is a newly developed econometric technique. The estimated results indicate that in the long-run real income, inflation rate, foreign interest rate and real effective exchange rate have a significant impact on real money balances in Pakistan. The dynamics of real money demand show that the effects of rate of inflation, foreign interest rate and the real effective exchange rate are much smaller in the short run than long run. The results also reveal that the demand for real money balances in Pakistan is stable, despite the economic reforms pursued by the government since the late 1980s.
\end{abstract}

\section{Introduction}

In the pursuit of a meaningful monetary policy, understanding the demand for money plays an important role. The analysis of money demand helps policy makers to forecast money demand and determine the optimum growth rate of money supply, which is crucial in the control of the rate of inflation. The identification of money demand is equally important as it plays a crucial role in the transmission mechanism of both monetary and fiscal policy. The demand for money balances is an essential ingredient in most traditional macroeconomic models. The stability of money demand function is vital to the performance of monetary policies, since it enables the money supply to have a specific predictable impact on real variables. The stability of money demand function may be affected by the structural changes in the economy and as a result the monetary targeting would become ineffective. In Pakistan several

\footnotetext{
* Associate Professor, Government Post-graduate College, Muzaffarabad (Azad Kashmir)

${ }^{* *}$ Assistant Professor, Government Post-graduate College, Muzaffarabad (Azad Kashmir)
} 
reforms have been carried out since the late 1980s to get rid of the imminent budgetary and balance of payments problems. These financial reforms have significantly changed Pakistan's financial system. The removal of foreign exchange controls and deregulation of financial markets have substantially changed the environment in which monetary policy operates. Government securities and inter bank markets have developed and deepened, interest rates are determined freely, and new indirect monetary controls have been developed. The impacts of subsequent reforms on financial sectors, foreign trade and commerce have not been examined within the context of Pakistan so far. This paper shows how inspite of financial liberalization and subsequent "boom and bust" of "bubbles" in the economy, a stable money demand function can be obtained by adopting an adequate econometric modeling strategy.

With the advent of the floating exchange rate since 1973, the literature has stressed the importance of including exchange rates and foreign interest rates as determinants of money demand for developed and developing countries. Tower (1975); Arango and Nadiri (1979, 1981), Arize (1989), McNown and Wallace (1992), Bahmani-Oskooee and Rhree (1994), Bahmani-Oskooee (1996) and Bahmani-Oskooee and Techaratanachai (2001) have shown the existence of a relationship between money demand and exchange rates. Similarly, Arango and Nadiri (1981) and Booth and Chawdhury (1992) have stressed the importance of foreign interest rates as a determinant of money demand because of its effects on the desired stock of real cash balances and exchange rate expectations. Few empirical studies have investigated the impact of the exchange rate on the demand for money in LDCs, and the results have been mixed.

Lee and Chung (1995) find that the exchange rate exerts negative and statistically significant effects on Korea's demand for money. Tan (1997) considers the demand for money in Malaysia and reports that the exchange rate has a statistically significant effect on real $M_{1}$ balances and no effect on real $M_{2}$ balances. Ibrahim (2001) re-examines Malaysian money demand and finds that the exchange rate has a negative effect on both real $M_{1}$ and real $M_{2}$ balances. Weliwata and Ekanayake (1998) study Sri Lanka's demand for money and find that the exchange rate has a significant negative effect on real $M_{1}$ balances. They fail to obtain a meaningful $\mathrm{M}_{2}$ relation. Money demand for a developing economy like Pakistan has been largely ignored. This paper tries to fill this gap.

The objective of this paper is to estimate money demand function for Pakistan by keeping in mind the recent developments in the money demand literature, which incorporates real exchange rates and foreign interest rates as additional arguments of the money demand function. For 
estimation purposes, we utilize quarterly data over the period 1982Q1 through 2002Q4 and the estimation technique will be Autoregressive Distributed Lag (ARDL) developed by Pesaran et al (2001).

The rest of the paper is organized as follows: section 2 presents the model specification. Data and econometric methodology are discussed in section 3. Empirical findings are presented in section 4, while concluding remarks along with some policy implications are given in the final section.

\section{Model Specification and Economic Theory}

In economic theories of money demand, money is determined for at least two reasons ${ }^{1}$. The first is as an inventory to smooth differences between income and expenditure streams, and the second, is as one among several assets in a portfolio. Both demands lead to a $\log$-linear specification such as:

$$
(m-p)_{t}=\beta_{0}+\beta_{1} y_{t}+\beta_{2} i_{t}+\beta_{3} \pi_{t}+\mu_{t}
$$

Where $m$ is logarithm of nominal money balances, $p$ is the logarithm of price level, $y$ is the logarithm of real GDP, $i$ is the interest rate variable, $\pi$ is the inflation rate and $\mu$ is the error term.

According to equation (1), real money balances are assumed to be an increasing function of real income, that is, $\beta_{1}$ is expected to be positive. The opportunity cost of holding money relative to financial assets $\left(i_{t}\right)$ is expected to yield a negative influence on money demand, so $\beta_{2}$ is expected to be negative. The opportunity cost of holding money (i.e. inflation rate) relative to real value of physical assets exerted negative effects on money demand, hence $\beta_{3}$ is expected to be negative. An increase in expected inflation should lead to substitution away from money to real assets.

The above framework may be appropriate for the closed economy, it is unlikely to be adequate for developing economies because foreign sector consideration plays a key role in the determination of their money demand function. Therefore, given the openness of these economies, including Pakistan, an appropriately specified money demand model should take account of foreign monetary developments, such as variation in exchange rates and foreign interest rate (Arango and Nadiri, 1981). The link between exchange rates and money demand can also be used to define currency substitution. The currency substitution literature suggests that portfolio shifts between domestic and foreign money provide a role for a foreign

\footnotetext{
${ }^{1}$ See for example Ericsson and Sharma (1996)
} 
exchange variable (Agenor and Khan, 1996) ${ }^{2}$. In contrast, the capital mobility literature focuses on the foreign interest rate variable (Ambler and McKinnon, 1985 and McKinnon, 1983).

Given the above background, the demand for real money balances in equation (1) is augmented with the real effective exchange rate $\left(q_{t}\right)$ and foreign interest rate $\left(i_{t}{ }^{*}\right)$, that is:

$(m-p)_{t}=\beta_{0}+\beta_{1} y_{t}+\beta_{2} i_{t}+\beta_{3} \pi_{t}+\beta_{4} i_{t}^{*}+\beta_{5} q_{t}+\mu_{t}$

An increase in the foreign interest rate $\left(i_{t}{ }^{*}\right)$ may raise the attractiveness of foreign bonds and induce domestic residents to transfer their financial assets to the high-yielding capital markets. Such a transfer will be financed by drawing down domestic money holdings ${ }^{3}$. Therefore, it can be postulated that an increase in the foreign interest rates will have a negative impact on the money demand, so $\beta_{4}$ is expected to be negative.

Arango and Nadiri (1981) have argued that a depreciation of the domestic currency increases the value of foreign securities held by the domestic residents. If this increase is perceived by the domestic security holders as an increase in their wealth, their demand for domestic cash balances may increase. Thus an increase in the real exchange rate (i.e. depreciation of Pak-rupee) is likely to increase the demand for money. In this case $\beta_{5}$ is expected to be positive. On the other hand, when the exchange rate depreciates for a net debtor country (as in Pakistan), the home currency value of wealth falls and this reduces the demand for money; hence the estimate of $\beta_{5}$ should be negative.

To summarize the expected signs for equation (2) are $\beta_{1}>0, \quad \beta_{2}, \beta_{3}, \beta_{4}<0$ and $\beta_{5}><0$. Based on the above discussion, an increase in the real exchange rate (i.e. depreciation of Pak-rupee) could have a positive or negative effect on the demand for real money balances; therefore, which effect dominates is an empirical issue.

\section{Data and Econometric Methodology}

${ }^{2}$ Mundell (1963) argued that the demand for money is likely to depend upon the exchange rate, in addition to the interest rate and the level of income. A portfolio model of the financial market explored by Arango and Nadiri (19981) provides a role of the exchange rate variable in the money demand function. However, they pointed out that the effect of the exchange rate is more difficult to sign.

${ }^{3}$ This is called capital mobility effect. 
The present study is based on quarterly data covering the period from 1982Q2 through 2002Q4, which include the 1990s reforms period as well. $M$ is the broad money, which includes all Pak-rupee denominated currency in circulation plus demand, time and foreign currency deposits. $\mathrm{P}$ is the price level proxied by the (CPI) Consumer Price Index $(2000=100)$. Y is the real GDP. Since the quarterly series on GDP are not available we generated quarterly series for GDP following Goldstein and Khan (1978). i is the interest rate variable proxied by the money market rate. $\pi$ is the inflation rate variable, which is calculated by taking the log-difference of CPI. $i^{*}$ is the foreign interest rate proxied by the US Federal Fund Rate, while $q$ is the trade weighted real effective exchange rate index composed by the IMF as a proxy for the exchange rate. All the data are taken from IFS CD-ROM. Since the estimated coefficient of the domestic interest rate is statistically insignificant hence in the empirical specification this variable is excluded from the analysis.

Since our intention is to detect the long run relationship between real money balances, real GDP, inflation rate, foreign interest rate and real effective exchange rate, the appropriate technique to be used is error correction modeling and cointegration analysis. In applying any cointegration technique, the first exercise is to determine the degree of integration of each variable in the model. This of course, will depend on which unit root test one can use. To avoid this difficulty and pre-testing of unit roots, Pesaran and Shin (1995) and Pesaran et al $(1996,2001)$ introduced a relatively new cointegration test know as Autoregressive Distributed Lag (ARDL) approach. This test has several advantages. One of its most notable features is that the existence of the long run relationship is tested without any a priori knowledge of the order of the time series (i.e. $I(0)$ or $I(1)$ ) of the possibility of cointegration. Since the power of existing unit root tests to identify the order of integration, in particular, whether $\mathrm{I}(0)$ or $\mathrm{I}(1)$ is always questionable, hence their test may be useful (Nagayasu, 1998). Another useful feature of this test is that it does not matter whether the explanatory variables are exogenous or not (Pesaran and Shin, 1997). The short-and long-run parameters with appropriate asymptotic inferences can be obtained by applying OLS to ARDL with an appropriate lag length. A general specification of this test can be expressed as:

$$
\Delta r m_{t}=\alpha_{0}+\alpha_{1} t+\gamma r m_{t-1}+\delta x_{t-1}+\sum_{i=1}^{\rho} \theta_{i} \Delta r m_{t-i}+\sum_{i=1}^{\rho} \phi_{i} \Delta x_{t-i}+\varepsilon_{t}
$$

Where $r m$ is the real money balances, $t$ is the time trend and $x$ is a vector of explanatory variables (.i.e. $y_{t}, \pi_{t}, i_{t}{ }^{*}, q_{t}$ ). Testing the existence of a long-run relationship can be conducted by examining the joint null hypothesis that $\gamma=\delta=0$ against the alternative that $\gamma \neq \delta \neq 0$ and 
therefore, this test resembles testing the existence of ECM after estimating the short-run dynamic specification. Existence of a long run relationship can be confirmed once this null is successfully rejected. A conventional distribution cannot be applied in this context. Pesaran et al provide critical values based on their stochastic simulation. The fact that their test considers two extreme cases: $\mathrm{I}(0)$ and $\mathrm{I}(1)$, leads to calculation of the two extreme critical values, which create the critical value band ${ }^{4}$. Therefore, the null hypothesis can be rejected when calculated F-values are greater than the upper boundary and cannot be rejected when they are less than the lower ceiling. When the F-values are within the band, the result is inconclusive.

\section{Empirical Results}

We implemented Pesaran et al (1996, 2001) cointegration test outlined in equation (3) in order to estimate the demand for real money balances for Pakistan over the period 1982Q2-2002Q4. In the first step, we have estimated equation (3) by imposing two, four and six lags on each first differenced variable and calculated F-tests. But when two lags are imposed, there is strong evidence for cointegration because our calculated F-statistic is 6.6933, which is greater than the critical value of the upper level of the band (i.e. 3.83) at the 5 percent level of significance. This result gives an indication for the existence of a long-run relationship between real money balances, real income, inflation rate, foreign interest rate and the real effective exchange rate. However, cointegration disappeared when we shift to four or six lags.

Once the cointegration is established, we move to the second stage of the procedure which involves estimating the error correction model represented by equation (3) by keeping the lagged level of variables and by relying upon a criterion we selected the appropriate lag order on each of the first differenced terms. After normalizing on real money balances, we obtain estimated long run coefficients represented by Table-1.

Table-1: Estimated Long-run Coefficients of Real Money Balances Using ARDL Approach

\begin{tabular}{cccc}
\hline \multicolumn{4}{c}{ Dependent Variable: $(m-p)_{t}$} \\
\hline Regressor & Coefficient & t-values & p-values \\
\hline$y_{t}$ & 1.00 & 23.74 & 0.000 \\
$\pi_{t}$ & -6.33 & -2.94 & 0.004 \\
\hline
\end{tabular}

${ }^{4}$ This cointegration test can be implemented by means of an F-test. The two set of critical values are tabulated by Pesaran et al (2001). 


\begin{tabular}{lrrr}
\hline$i_{t}{ }^{*}$ & -0.06 & -3.20 & 0.002 \\
$q_{t}$ & 0.23 & 2.25 & 0.030 \\
\hline
\end{tabular}

Note: ARDL (1, 1, 0, 0, and 0) selected on the basis of AIC

As can be seen from Table 1, the estimates possessed expected signs and are statistically significant at the 5 percent level of significance. The coefficient of real income is significant and equal to unity, indicating that a 1 percent increase in real GDP will lead to an equi-proportional increase in real money balances. The negative coefficient of inflation rate will exert a negative impact on the real money holdings. This indicates that in Pakistan people prefer to substitute real assets for money balances. The foreign interest rate variable has produced a negative influence on domestic money. However, the effect of this variable is relatively small. The real effective exchange rate will exert a positive effect on domestic real money balances. This result implies that in the long run, a 10 percent increase in the real effective exchange rate will increase, on average, the demand for real money balances by 2.3 percent per quarter. This finding is consistent with the wealth enhancing effect. Since $M_{2}$ is a more investment-oriented definition of money, the positive effect of the exchange rate on real money balances may be justified. Since the wealth holders evaluate their asset portfolio in terms of the Pak-rupee, a depreciation raises the domestic currency value of foreign assets and those wealth holders who see this as an increase in their wealth may repatriate part of their foreign assets to domestic assets, including $M_{2}$, in an attempt to maintain a fixed share of their wealth invested in domestic currency.

\section{Estimation of Short Run Dynamics}

The error correction regression associated with the above long run relationship based on the ARDL approach is reported in Table 2. The estimated lagged error correction term $\left(\mathrm{Ecm}_{t-1}\right)$ is negative and highly significant. This result supports the cointegration among the variables. The coefficient of the feed back parameter is -0.1188 , and suggests that, when real money balances exceed their long-run relationship with real income, inflation rate, foreign interest rate and real effective exchange rates, they adjust downwards at a rate of about 12 percent per quarter. This finding implies that: first, overlooking the cointegratedness of the variables would have introduced a misspecification in the underlying dynamic structure; second, there 
exist market forces in the monetary sector that operate to restore longrun equilibrium after a short-term adjustment; third, it takes a little above one year for 50 percent of the deviations from long-run equilibrium to be corrected.

Table-2: Error Correction Representation for Selected ARDL Model

\begin{tabular}{lclc}
\hline \multicolumn{4}{c}{ Dependent Variable: $\Delta(m-p)_{t}$} \\
\hline \multicolumn{1}{c}{ Regressor } & Coefficient & t-value & p-value \\
\hline$\Delta y_{t}$ & -0.2029 & -0.9513 & 0.345 \\
$\Delta \pi_{t}$ & -0.7520 & -3.5486 & 0.000 \\
$\Delta i_{t}^{*}$ & -0.0067 & -4.8470 & 0.000 \\
$\Delta q_{t}$ & 0.0277 & 3.1244 & 0.003 \\
$E c m_{(-1)}$ & -0.1188 & -3.3805 & 0.001 \\
$\mathrm{R}^{2}$ & 0.34 & $\mathrm{R}_{\text {adj }}^{2}$ & 0.30 \\
S.E. of Regression & 0.017 & $\mathrm{~F}(4,74)$ & $9.5488(0.000)$ \\
R.S.S & 0.02 & AIC & 205.5814 \\
LL & 211.584 & $\mathrm{DW}$ & 2.2506 \\
\hline
\end{tabular}

Note: ARDL (1, 1, 0, 0, and 0) selected on the basis of AIC. R.S.S, LL, AIC and DW are respectively residual sum of squares, $\log$ likelihood, Akike's Information Criteria and Durbin Watson Stat. Figures in brackets represents p-values and $E c m=(m-p)-1.00 y_{t}+6.33 \pi_{t}+0.06 i_{t}{ }^{*}-0.23 q_{t}$

From the empirical analysis, three points are worth mentioning. First, our results are not consistent with the hypothesis of an instantaneous adjustment of the growth of real money balances to departure from their equilibrium value in the previous period. Second, because $\mathrm{M}_{2}$ contains a savings component, hence the speed of adjustment is slow. Cuthberston and Taylor (1990) argue that slow speed of adjustment is based on the resident's precautionary saving motive being influenced by the long-run considerations of future income and the rates of return. Finally, the response of real exchange rate depreciation is about 0.03 per quarter. 
The results show that changes in real income is not statistically significant while changes in rate of inflation, foreign interest rate and real effective exchange rate have significant short-run effects. According to the results given in Table 3 , the short-run elasticities of the inflation rate, foreign interest rate and real exchange rate are $-0.75,-0.007$ and 0.03 respectively. Further more these elasticities are much lower than the long-run elasticities.

Moreover, when the estimated values of $\Delta(m-p)_{t}$ are fitted against the actual values, it performs well in terms of tracking the cyclical nature of the movements in Pakistan, represented by Figure-1.

\section{Figure-1}

\section{Plot of Actual and Fitted Values}

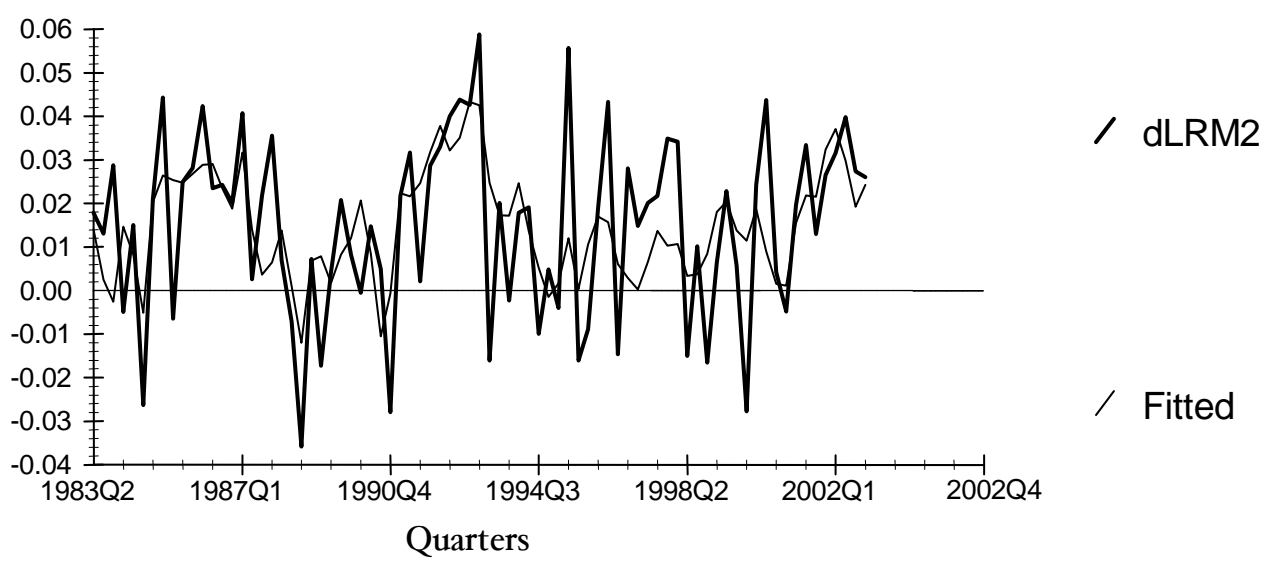

The estimated error correction model was found to be stable in terms of CUSUM of squares test. Figure 2 plots the CUSUM of squares of recursive residuals.

Figure-2 


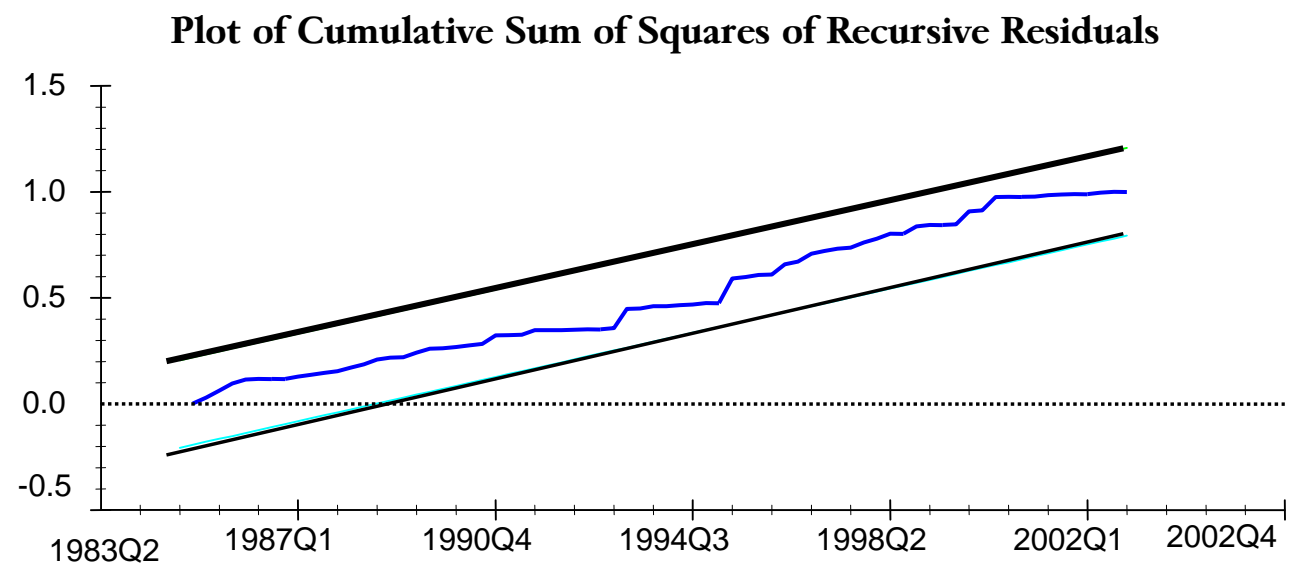

The straight lines represent critical bounds at 5\% significance level

CUSUM of squares path lies within the bands, indicating no structural change at the 5 percent level.

\section{Conclusions}

In this study a newly developed econometric technique by means of ARDL has been used to investigate empirically the fundamental issue of whether a long-run equilibrium relationship exists between real money balances and their determinants in Pakistan over the period 1982Q22002Q4. The empirical results reveal that there is a stationary long run relationship between real money balances, real income, inflation rate, foreign interest rate and real effective exchange rate. The analysis indicates that in the long run income elasticity is equal to one, in accordance with the predictions of the quantity theory of money. The opportunity cost of holding money (i.e. inflation rate) exhibits the correct sign. Furthermore, real income and the rate of inflation are the two important determinants of domestic money holdings in Pakistan. This implies that domestic asset holders view the holding of physical assets as an attractive alternative to monetary assets because in the long run real assets substitution is strong both in the short as well as in the long run. Moreover, the response of the foreign interest rate is very low both in the short and long run. The impact of real effective exchange rate on real money balances is positive and significant in the long run. However, this impact is low in the short run. The error correction is negative and significant, indicating that about 12 percent adjustment towards long run equilibrium takes place in one quarter. Finally, the result also indicates that demand for real money balances in Pakistan remained stable throughout the period under investigation. 
Important policy implications derived from the above findings are:

- The relative effectiveness of monetary and fiscal policies could be altered. For example, if an expansionary monetary policy is implemented in a situation where confidence in the domestic currency is lacking, its effectiveness may be compromised, leading to poor economic growth.

- The rebalancing effect resulting from variations in the real exchange rate play a key role in Pakistan's money demand behavior. 


\section{References}

Agenor, P.R. and Khan, M.S. 1996, "Foreign Currency Deposits and Demand for Money in Developing Countries", Journal of Development Economics, Vo1. 50, June, pp.101-118.

Ambler, S. and McKinnon, R. 1985, "US Monetary Policy and the Exchange Rate: Comment”, American Economic Review, Vo1.75, pp. 557-559.

Arango, S. and Nadiri, I.M. 1979, "Price Expectations, Foreign Exchange and Interest Rates, and Demand for Money in an Open Economy", Working Paper No. 359, National Bureau of Economic Research (NBER), Cambridge, M.A, June (1979).

1981, "Demand for Money in Open Economies", Journal of Monetary Economics, Vo1.7, No.1, pp. 69-83.

Arize, A.C. 1989, "An Econometric Investigation of Money Demand Behaviour in Four Asian Developing Economies", International Economic Journal, Vo1.3, pp.79-93.

Bahmani-Oskooee, M. 1996, "The Black Market Exchange Rate and Demand for Money in Iran”, Journal of Macroeconomics, Vo1.18, pp.171-176.

and H.J. Rhree 1994, "Long-run Elasticities of the Demand for Money in Korea: Evidence from Cointegration Analysis", International Economic Journal, Vo1.8, No.2, pp.83-93.

and A. Techaratanchai 2001, "Currency Substitution in Thailand”, Journal of Policy Modelling, Vo1.23, No.2, pp.141-145.

Booth, G., and M. Chowdhury 1992, "Canadian Foreign Exchange Policies: Intervention, Control, Cointegration”, Weltwirtschafliches Archv, Vo1.128, No.1, pp.21-33.

Cuthberston, K. and Taylor, M.P. 1990, "Money Demand, Expectations, and the Forward-looking Model”, Journal of Policy Modelling, Vol.12, No.1, pp. 289-315.

Ericsson, N.R, and Sunil Sharma 1996, "Broad Money Demand and Financial Liberalization in Greece”, Board of Governors of the Federal Reserve System, International Finance Discussion Paper No. 559, July 1996. 
Das, S. and K. Manda1 2000, "Modeling Money Demand in India: Testing Weak, Strong \& Super Exogeneity”, Indian Economic Review, Vo1. XXXV, No.1, pp.1-19.

Goldstein, M., and M.S. Khan 1976, "Large Versus Small Price Changes in the Demand for Imports”, IMF Staff Papers, Vol.23, pp.200-225.

Ibrahim, M.H. 2001, "Financial Factor and the Empirical Behaviour of Money Demand: A Case Study of Malaysia”, International Economic Journal, Vol.15, No.3, pp.55-72.

Lee, T.H. and K.J. Chung 1995, "Further Results of the Long-run Demand for Money in Korea”, International Economic Journal, Vo1.9, Autumn, pp. 103-113.

McKinnon, R.I. 1983, "Currency Substitution and Instability in the World Dollar Standard”, American Economic Review, Vo1. 27, pp 320-333.

McNown, R., and M. Wallace 1992, "Cointegration Tests of a Long-run Relation between Money Demand and the Effective Exchange Rate", Journal of International Money and Finance, Vo1.11, pp. 107-114.

Munde11, A.R. 1963, "Capital Mobility and the Stabilization Policy under Fixed and Flexible Exchange Rates”, Canadian Journal of Economics and Political Science, Vo1.29, pp. 475-485.

Nagayasu. J. 1998, "Japan, Effective Exchange Rates and Determinants: Prices, Real Interest Rates, and Actual and Optimal Current Accounts”, IMF Working Paper No. WP/98/86, International Monetary Fund, Washington D.C.

Pesaran, M.H. and Y. Shin 1995, "An Autoregressive Distributed Lag Modelling Approach to Cointegration Analysis”, In S. Strom, A. Holly, and P. Diamond (eds), Centennial Volume of Ranger Frisch, Cambridge: Cambridge University Press.

1997, “An Autoregressive Distributed Lag Modelling Approach to Cointegration Analysis”, (Cambridge: Department of Applied Economics, Cambridge University).

Pesaran, M.H., Y. Shin and R.J. Smith 1996, "Testing for the Existence of a Long-Run Relationship”, Department of Applied Economics Working Paper No. 9622, University of Cambridge. 
2001, "Bound Testing Approaches to the Analysis of Level Relationships", Journal of Applied Econometrics, Vol. 16, pp. 289-326.

Qayyum, A. 2000, "Demand for Real Money Balances by the Business Sector: An Econometric Investigation”, The Pakistan Development Review, Vol. 39, No.4, pp.857-873.

2001, "Sectoral Analysis of the Demand for real Money Balances in Pakistan”, The Pakistan Development Review, Vol.40, No. 4, pp.953-966.

Tower, E. 1975, "Money Demand and the Terms of Trade", Weltwirtschafliches Archv, Vol.111, No.4, pp.623-633.

Tan, E.C. 1997, "Money Demand Aimed Financial Sector Development in Malaysia”, Applied Economics, Vo1. 29, No.9, pp.1201-1215.

Weliwita, A. and Ekanayake, E.M. 1998, "Demand for Money in Sri Lanka during the Post-1977 period: Cointegration and Error Correction Analysis", Applied Economics, Vol, 30, No. 9, pp.1219-1229. 